\title{
PENGARUH WOVEN ANGLE DAN PROSES PENEKANAN TERHADAP TEGANGAN TARIK PADA NATURAL FIBER LAMINATE COMPOSITE
}

\author{
Khairul Anam, Anindito Purnowidodo, Sofyan Arief Setyabudi \\ Jurusan Teknik Mesin Fakultas Teknik Universitas Brawijaya \\ Jl. Mayjen Haryono No. 167, Malang, 65145, Indonesia \\ E-mail: khairul.anam27@ub.ac.id
}

\begin{abstract}
The aim of this study is to investigate the effects of pressure and woven angle on the tensile strength of natural fiber laminate composite. Pandanus tectorius and polymethyl methacrylate (PMMA) was used as natural fiber and matrix, respectively. The epoxy adhesive joint is used to connect between natural fiber and matrix. The pressure time of $10 \mathrm{~s}, 15 \mathrm{~s}, 30 \mathrm{~s}$ and the pressure of $20 \mathrm{~N} / \mathrm{mm}^{2}, 40 \mathrm{~N} / \mathrm{mm}^{2}, 60 \mathrm{~N} / \mathrm{mm}^{2}$ were used in this study. In addition, the angle of the $0^{\circ} / 90^{\circ}$ and $45^{\circ} / 45^{\circ}$ woven angle is used as the initial reference for fiber orientation before pressure is applied. From the results of the study, it can be concluded that the addition of a pressure of $60 \mathrm{~N}$ $/ \mathrm{mm}^{2}$ and pressure time of $30 \mathrm{~s}$ has the highest tensile strength both at the angle of $0^{\circ} / 90^{\circ}$ and $45^{\circ} / 45^{\circ}$. However, the tensile strength at the angle of $0^{\circ} / 90^{\circ}$ is higher that $45^{\circ} / 45^{\circ}$. In addition, the number of adhesives decreased with increasing the pressure which will lead to delaminating.
\end{abstract}

\section{Keywords: Tensile Strength, Woven Angle, Pressure, Natural Fiber, Laminate Composite}

\section{PENDAHULUAN}

Penggunaan komposit dalam kehidupan sehari - hari semakin berkembang tidak hanya sampai bidang kapal laut, industri otomotif, dan industri pesawat terbang tetapi kegunaan komposit telah merambah ke bidang lainnya seperti industri elektronik, industri alat alat rumah tangga dan industri alat olah raga [1]. Material komposit merupakan gabungan dari dua atau lebih material yang memiliki fasa yang berbeda menjadi suatu material baru yang memiliki properti lebih baik dari keduanya dan terjadi dalam skala makroskopis (dapat terlihat langsung oleh mata). Salah satu keunggulan dari komposit adalah memiliki perbandingan kekuatan dengan berat yang lebih baik daripada logam $[2,3]$. Salah satu jenis komposit yang paling sering digunakan sebagai struktur adalah laminate composite. Dimana konfigurasinya berupa logam-komposit-logam, non logam-komposit-non logam dan logamkomposit-non logam. Komposit sendiri dapat diperkuat dengan menggunakan serat atau serbuk [4].

Seiring dengan perkembangannya, penerapan komposit dalam kehidupan seharihari tidak terlepas dari isu lingkungan karena sulit terurai. Oleh sebab itu, komposit yang ramah lingkungan, mudah terurai, sustainable, dan dapat diperbaharui merupakan salah satu syarat yang penting dalam proses pembuatan komposit $[5,6]$. Oleh sebab itu, penggunaan natural fiber sangat dibutuhkan sebagai penguat komposit yang mana juga memiliki harga yang relatif murah [6,7]. Akan tetapi, properti mekanik dari setiap natural fiber sangat bervariasi sehingga akan berpengaruh terhadap kekuatannya [8].

Penelitian mengenai pembuatan komposit menggunakan serat daun pandan laut (pandanus tectorius) sebagai filler masih jarang ditemui. Adanya beberapa penelitian mengenai kegunaan komposit serat alam lebih menguntungkan dari segi pembuatan. Kekuatan pada komposit dipengaruhi juga oleh faktor-faktor seperti temperatur, tebal matrik, dan sudut penyusunan seratnya. Serat daun pandan tergolong pada cellulosic materials yang memiliki karakteristik mechanic yang bagus dan stabilitas yang bagus terhadap temperatur [9-11].

Jufra melakukan penelitian tentang pengaruh fraksi volume serat pelepah gebang (Corypha Utan Lamarck) terhadap sifat mekanik pada komposit bermatrik epoksi. Dari hasil penelitiannya didapatkan bahwa kekuatan tarik dan kekuatan impak meningkat seiring meningkatnya fraksi volume serat [4]. Budha maryanti juga melakukan investigasi pada engaruh alkalisasi komposit serat kelapa- 
poliester terhadap kekuatan tarik. Hasil research). Pada penelitian ini akan diuji penelitiannya menyimpulkan bahwa pengaruh woven angle dan proses penekanan peningkatan persentase alkalisasi dapat terhadap kekuatan tarik natural fiber laminate meningkatan kekuatan tarik komposit [10]. composite. Dimensi spesimen yang akan diuji Rusman Nur Ichsan melakukan penelitan di penelitian ini ditunjukkan oleh Gambar 1. tentang pengaruh susunan lamina berpenguat serat E-glass dan serat karbon terhadap kekuatan tarik. Dari hasil penelitiannya didapatkan bahwa kekuatan tarik tertinggi adalah carbon fiber laminate composite dengan rata-rata 265,99 $\mathrm{MPa}$ dan terendah adalah Eglass random laminate composite dengan ratarata 115,01 MPa. Selain itu, serat E-glass WR dan serat Hybrid memiliki kekuatan tarik ratarata yang hampir sama yaitu masing-masing 196,30 MPa dan 198,25 MPa [12]. Nopriantina telah meneliti pengaruh ketebalan serat pelepah Pisang Kepok (Musa Paradisiaca). Ketebalan serat yang digunakan adalah 0,67 $\mathrm{mm}, 0,70 \mathrm{~mm}, 0,80 \mathrm{~mm}, 0,82 \mathrm{~mm}$. Metode hand lay-up digunakan untuk membuat spesimen komposit dengan mengacu pada ASTM ASTM D638 untuk kekuatan tarik. Dari hasil penelitian yang dilakukan ternyata komposit dengan ketebalan 0,82 $\mathrm{mm}$ memiliki kekuatan tarik paling optimal [13].

Berdasarkan uraian diatas, penelitian tentang woven angle dan pengaruh proses penekanan sangat penting untuk dilakukan untuk mengetahui kekuatan tarik natural fiber laminate composite. Selain itu, proses penekanan juga akan berpengaruh pada ketebalan material komposit, Hal ini juga akan mempengaruhi kekuatan tarik dari komposit itu sendiri sesuai dengan penelitian yang sudah dilakukan oleh Nopriantina.

Kekuatan tarik adalah kemampuan suatu bahan dalam menahan beban tarik yang diberikan pada benda tersebut. Fokus utama pada kekuatan tarik adalah kekuatan maksimum atau sering disebut UTS (Ultimate Tensile Strength) [14] dimana nilai UTS dapat dihitung menggunakan Pers. 1.

$\sigma=\frac{F \max }{A}$

Keterangan :

Fmax = Gaya maksimum (N)

A $\quad=$ Luas penampang $\left(\mathrm{mm}^{2}\right)$

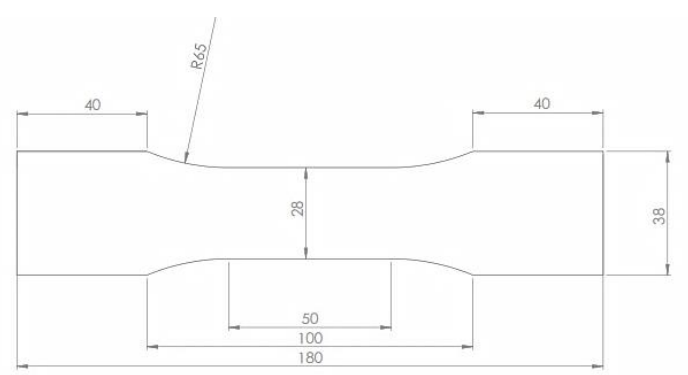

Gambar 1. Dimensi spesimen dengan satuan dalam $\mathrm{mm}$.

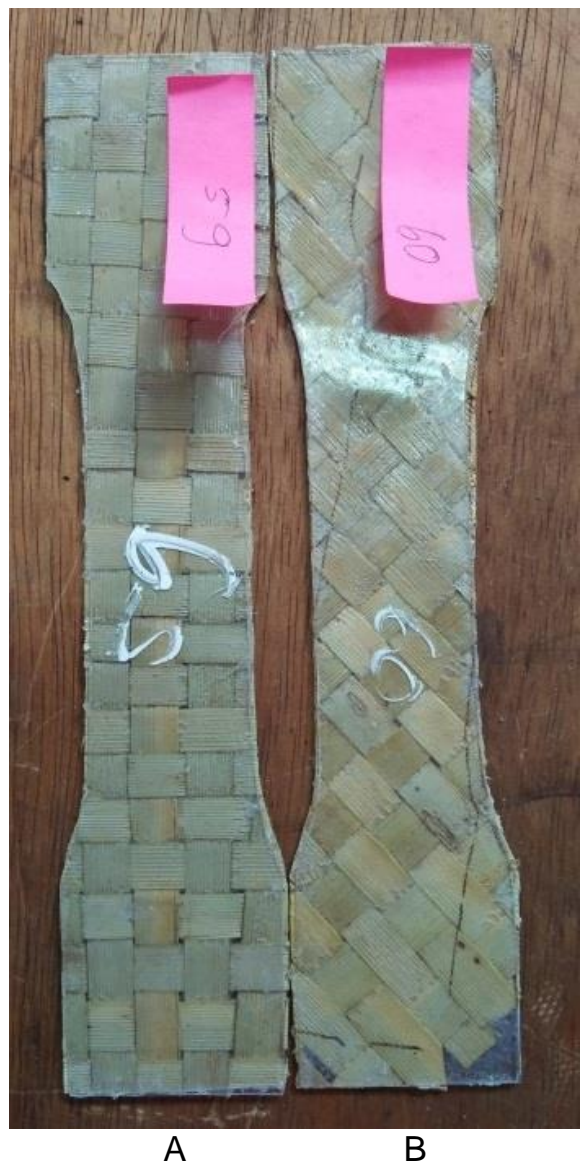

Gambar 2. Sudut woven serat $A\left(0^{\circ} / 90^{\circ}\right)$ dan $B\left(45^{\circ} /-45^{\circ}\right)$ sebelum proses penekanan

\section{METODOLOGI PENELITIAN}

Penelitian ini menggunakan metode eksperimental nyata (true experimental

Pada penelitian ini besar penekanan divariasikan mulai $20 \mathrm{~N} / \mathrm{mm}^{2}, 40 \mathrm{~N} / \mathrm{mm}^{2}$ dan 60 
$\mathrm{N} / \mathrm{mm}^{2}$ dan lama penekanan divariasikan mulai $10 \mathrm{~s}, 15 \mathrm{~s}, 30 \mathrm{~s}$. Selain itu, sudut woven $0^{\circ} / 90^{\circ}$ dan $45^{\circ} /-45^{\circ}$ dipakai sebagai acuan awal orientasi fiber sebelum dilakukan penekanan. Gambar 2 menunjukkan sudut woven sebelum proses penekanan.

\section{Material properties}

Spesimen pada penelitian ini dibagi menjadi 3 bagian yaitu mika/PMMA - natural fiber composite - mika/PMMA (non logamkomposit-non logam). PMMA adalah matriks polimer yang digunakan dalam penelitian ini. PMMA sendiri termasuk ke dalam jenis resin yang tebus pandang atau biasa kita sebut mika. Properti mekanik PMMA dapat dilihat pada Tabel 1. Serat daun pandan merupakan serat alami yang paling banyak digunakan serta mudah dalam proses pembuatannya. Dalam penelitian serat daun pandan ini dijadikan sebagai natural fiber composite. Kekuatan tarik maksimum serat daun pandan adalah 1-3 MPa.

Tabel 1. Properti mekanik PMMA [15]

\begin{tabular}{lc}
\hline \multicolumn{1}{c}{ Mechanical Properties } & Value \\
\hline Hardness, Rockwell M & $63-97$ \\
Tensile Strength & $47-79 \mathrm{MPa}$ \\
Tensile Modulus & $2,2-3,8 \mathrm{GPa}$ \\
\hline
\end{tabular}

\section{Persiapan spesimen}

Pembuatan spesimen natural fiber laminate composite dilakukan melalui beberapa tahapan. Pertama, spesimen mika dibuat sesuai dengan desain. Kedua, membuat campuran epoksi adhesive dengan hardener dengan perbandingan 1:1, kemudian diaduk secara merata dan didiamkan selama 30 detik. Ketiga, mendistribusikan epoksi adhesive pada mika pertama secara merata. Keempat, merekatkan serat pada mika yang sudah di beri epoksi adhesive. Kelima, masukkan laminate composite tersebut ke dalam cetakan yang sudah diberi lilin atau glaze agar komposit tidak menempel pada cetakan. Keenam, pindahkan cetakan komposit tesebut pada mesin press untuk dapat perlakuan terlebih dahulu. Mesin Press yang digunakan memiliki spesifikasi maksimum tekanan sebesar $300 \mathrm{~kg} / \mathrm{cm}^{2}$. Alat penekan dapat dilihat pada Gambar 3. Setelah melewati proses pembuatan komposit maka komposit diuji tarik dengan alat hydraulic servo pulser seperti yang ditunjukkan pada Gambar 4.
Alat ini merupakan mesin untuk pengujian fatigue, creep, dan tarik. Dengan spesifikasi mesin max static load sebesar $\pm 50 \mathrm{kN}$ ( Range $1-50 \mathrm{kN}$ ). Pada alat tersebut komposit yang diuji tarik akan menghasilkan data berupa file yang akan di simpan di dalam komputer. Sehingga kita akan dapat langsung mengolah data tersebut.
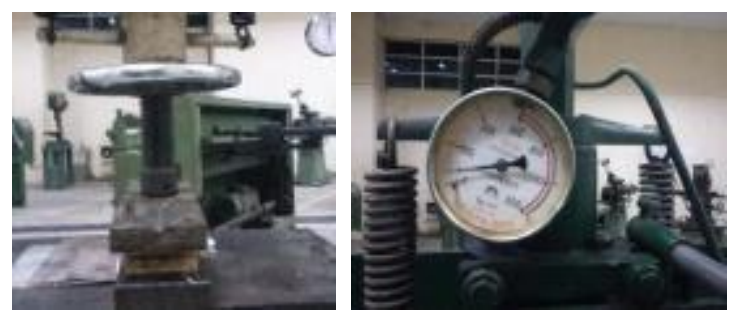

Gambar 3. Mesin press

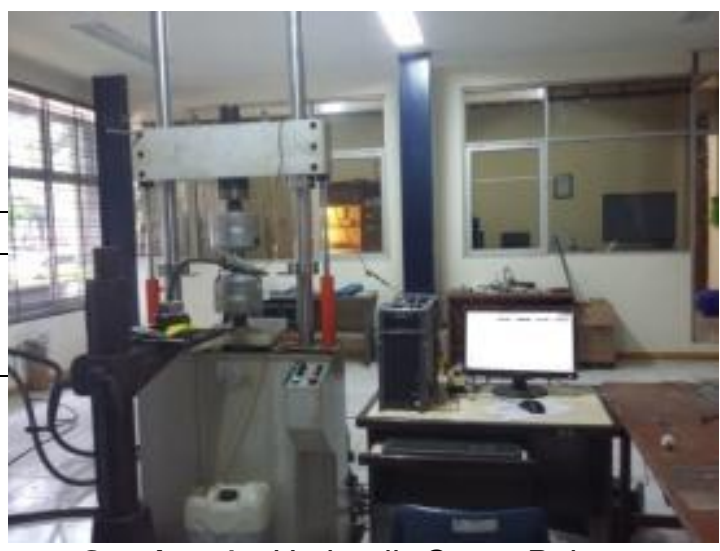

Gambar 4. Hydraulic Servo Pulser

\section{HASIL DAN PEMBAHASAN}

Pengaruh proses penekanan terhadap kekuatan tarik

Dari proses pengujian tarik komposit menggunakan mesin hydraulic servo pulser di dapatkan seperti yang ditunjukkan pada Gambar 5 dan 6. Gambar 5 merupakan hubungan antara kekuatan tarik komposit dengan variasi sudut woven pada tekanan berbeda dan waktu konstan. Dapat dilihat bahwa semakin besar tekanan yang diberikan pada komposit maka kekuatan tariknya akan bertambah besar juga. Dari Gambar 5 juga dapat kita lihat bahwa komposit dengan variasi sudut $0^{\circ} / 90^{\circ}$ memiliki kekuatan tarik lebih besar dibandingkan variasi sudut $45^{\circ} / 45^{\circ}$. Kekuatan tarik tertinggi pada komposit sudut $0^{\circ} / 90^{\circ}$ adalah sebesar $34.389 \mathrm{~N} / \mathrm{mm}^{2}$ dan untuk komposit sudut $45^{\circ} / 45^{\circ}$ adalah sebesar 31.671 
$\mathrm{N} / \mathrm{mm}^{2}$. Hal ini dapat memberikan indikasi bahwa komposit yang mendapatkan tekanan akan membuat distribusi perekat pada laminate akan merata. Sehingga matriks dan serat akan melekat dengan baik dan akan menaikkan kekutan tarik.

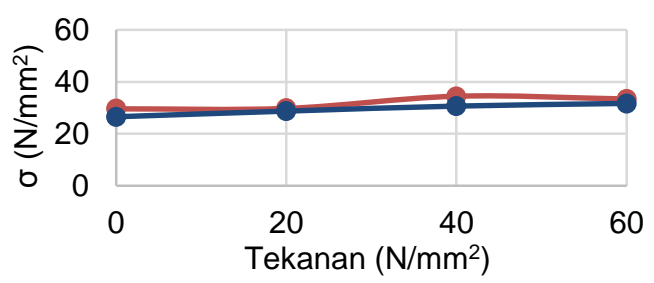

$\longrightarrow$ sudut $0^{\circ} / 90^{\circ} \longrightarrow$ sudut $45^{\circ} /-45^{\circ}$

Gambar 5. Kekuatan tarik maksimum komposit dengan sudut serat $0 \% 190^{\circ}$ dan sudut serat $45^{\circ} / 45^{\circ}$ pada besar penekanan berbeda dan waktu konstan (15 s)

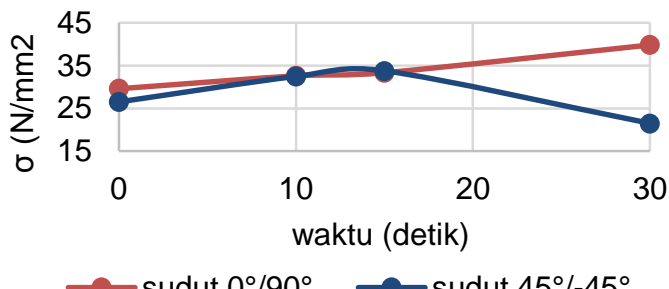

Gambar 6. Kekuatan tarik maksimum komposit dengan sudut serat $0^{\circ} / 90^{\circ}$ dan sudut serat $45^{\circ} \%-45^{\circ}$ pada waktu penekanan berbeda dan besar tekanan konstan konstan $\left(60 \mathrm{~N} / \mathrm{mm}^{2}\right)$

Dari Gambar 6 dapat dilihat perbandingan kekuatan tarik akibat adanya variasi lama penekanan pada $60 \mathrm{~N} / \mathrm{mm}^{2}$ baik pada spesimen dengan serat sudut $0^{\circ} / 90^{\circ}$ maupun spesimen dengan serat sudut $45 \%-45^{\circ}$. Pada spesimen dengan serat sudut $0^{\circ} / 90^{\circ}$ mencapai kekuatan maksimalnya sebesar $39.792\left(\mathrm{~N} / \mathrm{mm}^{2}\right)$. Pada spesimen dengan sudut serat $45 \%-45^{\circ}$ kekuatan maksimalnya sebesar 33.728 $\left(\mathrm{N} / \mathrm{mm}^{2}\right)$. Pada spesimen dengan sudut serat $0 \% 190^{\circ}$ grafiknya cenderung meningkat terus sampai lama penekanan 30 detik, sedangkan pada spesimen dengan sudut $45^{\circ}$ kekuatannya sudah menurun ketika spesimen yang diberi penekanan waktu lebih dari 15 detik. Hal ini disebabkan dengan lamanya penekanan yang diberikan pada spesimen, menyebabkan semakin banyaknya volume perekat yang keluar dari spesimen itu sendiri. semakin banyak volume perekat yang keluar, maka dapat mempengaruhi kekuatannya. Selain disebabkan pengaruh volume perekat yang keluar, faktor lain juga berpengaruh terhadap kekuatan tariknya, seperti gas yang terperangkap pada saat proses produksi, kekasaran permukaan antar serat dengan matriks dan faktor lainnya.

\section{Perilaku patahan spesimen dengan sudut $0 \% 90^{\circ}$ dengan variasi tekanan dan waktu penekanan $15 \mathrm{~s}$}

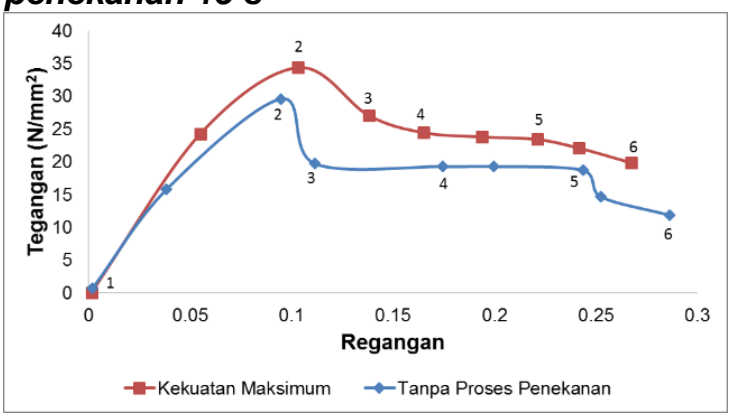

Gambar 7. Diagram tegangan-regangan spesimen dengan sudut $0 \% 90^{\circ}$ dengan waktu penekanan $15 \mathrm{~s}$

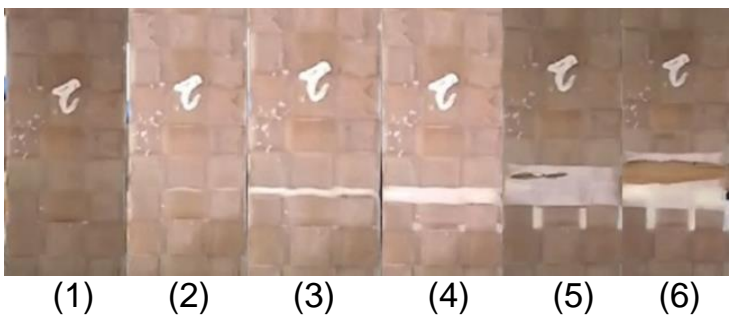

Gambar 8. Fase patahan spesimen dengan sudut $0 \% 90^{\circ}$ tanpa penekanan

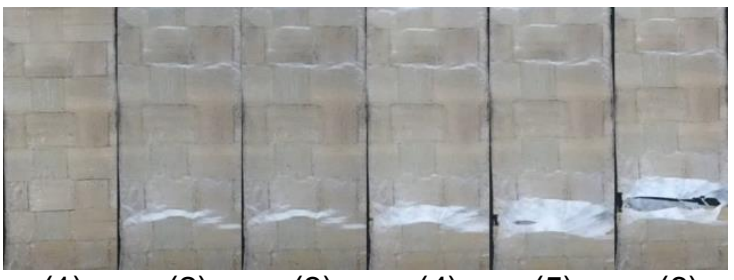

(1)

(2)

(3)

(4)

(5)

(6)

Gambar 9. Fase patahan spesimen dengan sudut $0^{\circ} / 90^{\circ}$ yang memiliki kekuatan paling tinggi dengan penekanan $40 \mathrm{~N} / \mathrm{mm}^{2}$

Gambar 7 menunjukkan diagram tegangan-regangan spesimen dengan sudut $0^{\circ} / 90^{\circ}$ dengan waktu penekanan $15 \mathrm{~s}$ antara 
spesimen dengan nilai kekuatan maksimum dan spesimen tanpa penekanan. Sedangkan Gambar 8 dan 9 merupakan fase patahan yang terjadi pada kedua spesimen sesuai dengan posisi yang ditunjukkan pada Gambar 7. Pada Gambar 8 dan 9, poin nomor (1) adalah kondisi awal spesimen saat proses uji tarik dimulai. Pada poin (2) sampai (3) kondisi pada spesimen mulai timbul daerah patahan yang terbentuk semakin melebar. (4) pada spesimen serat daun pandan sudah sepenuhnya patah tetapi mika pada spesimen belum patah dan terjadi delaminasi. (5) pada spesimen mika mulai mengalami putus. (6) pada spesimen $0 \% / 90^{\circ}$ sudah mengalami putus seluruhnya. Dari Gambar 8 dan 9 dapat dilihat bahwa saat proses pengujian terjadi delaminasi dimana delaminasi adalah suatu keadaan dimana antara matrik dan serat tidak menempel secara merata. Pada spesimen tanpa tekanan delaminasi bisa terjadi karena ikatan yang terbentuk dengan serat dan mika tidak terlalu sempurna sehingga daya rekatnya rendah. Hal ini yang akan menjadi pemicu munculnya delaminasi. Berbeda dengan spesimen yang memiliki kekuatan tarik tertinggi, munculnya delaminasi lebih lama dibandingkan spesimen tanpa penekanan karena proses penekanan dapat membantu untuk mendistribusikan perekat ke semua area.

\section{Perilaku patahan spesimen dengan sudut $45 \%-45^{\circ}$ dengan variasi waktu penekanan 15} $\boldsymbol{s}$

Gambar 10 menunjukkan diagram tegangan-regangan spesimen dengan sudut $45^{\circ} /-45^{\circ}$ dengan waktu penekanan $15 \mathrm{~s}$ antara spesimen dengan nilai kekuatan maksimum dan spesimen tanpa penekanan. Sedangkan Gambar 11 dan 12 merupakan fase patahan yang terjadi pada kedua spesimen sesuai dengan posisi yang ditunjukkan pada Gambar 10. Pada Gambar 11 dan 12, poin nomor (1) adalah kondisi awal spesimen saat proses uji tarik dimulai. Pada poin (2) sampai (3) kondisi pada spesimen mulai timbul daerah patahan yang terbentuk semakin melebar. (4) pada spesimen serat daun pandan sudah sepenuhnya patah tetapi mika pada spesimen belum patah dan terjadi delaminasi. (5) pada spesimen mika mulai mengalami putus. (6) pada spesimen $45^{\circ} / 45^{\circ}$ sudah mengalami putus seluruhnya. Dari Gambar 11 dan 12 dapat dilihat bahwa saat proses Pengujian juga terjadi delaminasi seperti halnya spesimen $0 \% 90^{\circ}$ akan tetapi delaminasi yang terjadi pada spesimen dengan kekuatan maksimum sedikit lebih luas daripada spesimen tanpa proses penekanan.

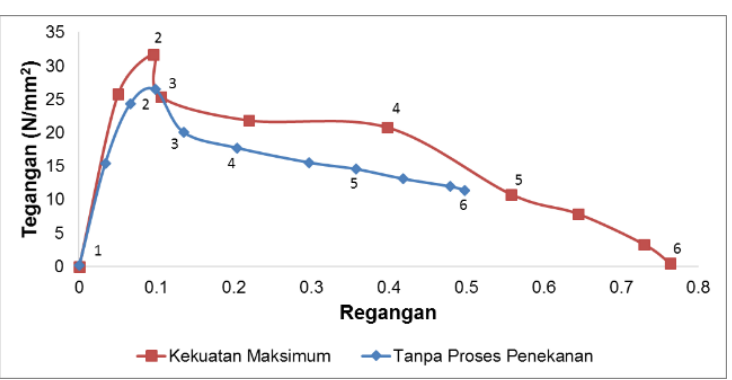

Gambar 10. Diagram tegangan-regangan spesimen dengan sudut $45 \%-45^{\circ}$ dengan waktu penekanan $15 \mathrm{~s}$

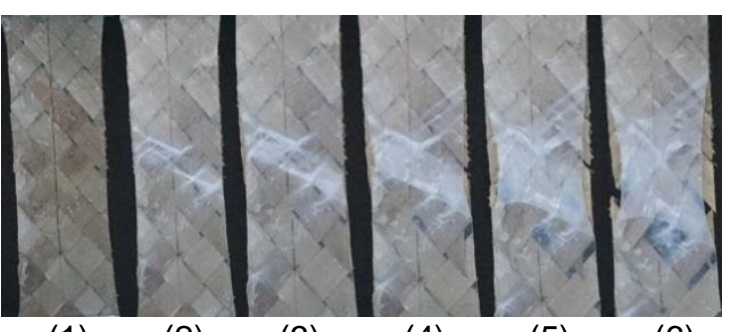
(1)
(2)
(3)
(4)
(5)

(6)

Gambar 11. Fase patahan spesimen dengan sudut $45^{\circ} /-45^{\circ}$ tanpa penekanan
(1)

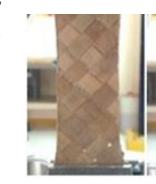

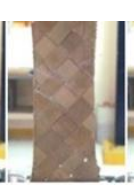

(2)

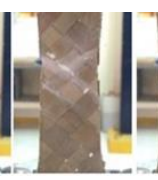

(3)

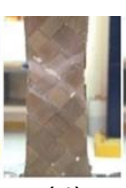

(4)

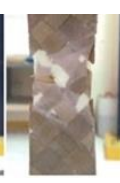

(5)

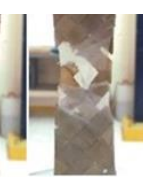

(6)
Gambar 12. Fase patahan spesimen dengan sudut $45^{\circ} / 45^{\circ}$ yang memiliki kekuatan paling tinggi dengan penekanan $60 \mathrm{~N} / \mathrm{mm}^{2}$

\section{Perilaku patahan spesimen dengan sudut $0 \% 90^{\circ}$ dengan variasi lama penekanan dan tekanan $60 \mathrm{~N} / \mathrm{mm}^{2}$}

Gambar 13 menunjukkan diagram tegangan-regangan spesimen dengan sudut $0 \% 90^{\circ}$ dengan variasi lama penekanan dan tekanan $60 \mathrm{~N} / \mathrm{mm}^{2}$ antara spesimen dengan nilai kekuatan maksimum dan spesimen tanpa penekanan. Sedangkan Gambar 14 merupakan fase patahan yang terjadi pada spesimen sesuai dengan posisi yang ditunjukkan pada Gambar 13. Pada Gambar 14, poin nomor (1) 
adalah kondisi awal spesimen saat proses uji tarik dimulai. Pada poin (2) sampai (3) kondisi pada spesimen mulai timbul daerah patahan yang terbentuk semakin melebar. (4) pada spesimen serat daun pandan sudah sepenuhnya patah tetapi mika pada spesimen belum patah dan terjadi delaminasi. (5) pada spesimen mika mulai mengalami putus. (6) pada spesimen $0 \% 90^{\circ}$ sudah mengalami putus seluruhnya. Dari Gambar 14 dapat dilihat adanya pull out yang terjadi pada spesimen. Pull out adalah keadaan dimana beban yang diterima komposit terlebih dahulu diterima seratnya sehingga serat patah terlebih dahulu. $\mathrm{Hal}$ ini dapat disebabkan karena kurang meratanya gaya pembebanan yang diterima serat dan matriks. Selain mengalami pull out, pada spesimen juga terjadi delaminasi sebelum patah.

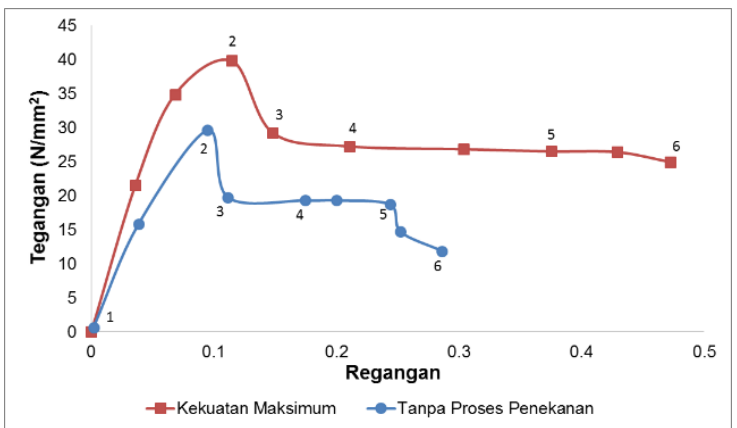

Gambar 13. Diagram tegangan-regangan spesimen dengan sudut $0^{\circ} / 90^{\circ}$ dengan besar penekanan $60 \mathrm{~N} / \mathrm{mm}^{2}$

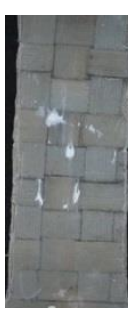

(1)

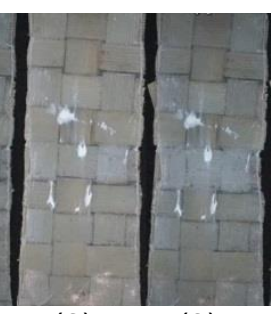

(2)
(3)

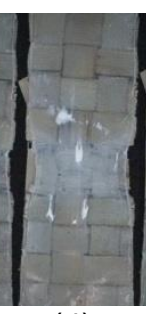

(4)

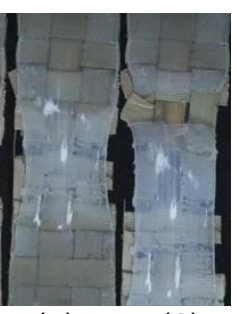

(5)
(6)
Gambar 14. Fase patahan spesimen dengan sudut $0 \% 90^{\circ}$ yang memiliki kekuatan paling tinggi dengan waktu penekanan $30 \mathrm{~s}$

\section{Perilaku patahan spesimen dengan sudut $45 \%-45^{\circ}$ dengan variasi lama penekanan dan tekanan $60 \mathrm{~N} / \mathrm{mm}^{2}$}

Gambar 15 menunjukkan diagram tegangan-regangan spesimen dengan sudut $45^{\circ} / 45^{\circ}$ dengan variasi lama penekanan dan tekanan $60 \mathrm{~N} / \mathrm{mm}^{2}$ antara spesimen dengan nilai kekuatan maksimum dan spesimen tanpa penekanan. Sedangkan Gambar 16 merupakan fase patahan yang terjadi pada kedua spesimen sesuai dengan posisi yang ditunjukkan pada Gambar 15. Pada Gambar 16 dan 12, poin nomor (1) adalah kondisi awal spesimen saat proses uji tarik dimulai. Pada poin (2) sampai (3) kondisi pada spesimen mulai timbul daerah patahan yang terbentuk semakin melebar. (4) pada spesimen serat daun pandan sudah sepenuhnya patah tetapi mika pada spesimen belum patah dan terjadi delaminasi. (5) pada spesimen mika mulai mengalami putus. (6) pada spesimen $45^{\circ} /-45^{\circ}$ sudah mengalami putus seluruhnya. Dari Gambar 16 dapat dilihat bahwa spesimen dengan sudut $45^{\circ} / 45^{\circ}$ tanpa proses penekanan yang ditunjukkan oleh Gambar 11 cenderung mengalami delaminasi lebih besar daripada spesimen sudut $45 \%-45^{\circ}$ dengan kekuatan maksimal sehingga spesimen tanpa proses penekanan mengalami fase mulur lebih lama sedikit dibandingkan spesimen dengan kekuatan maksimum.

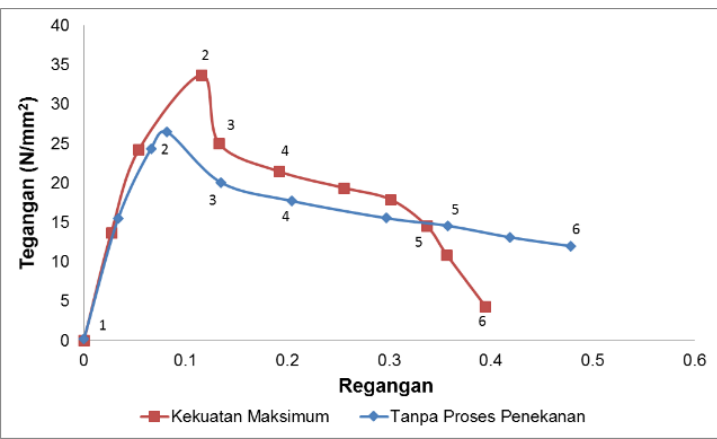

Gambar 15. Diagram tegangan-regangan spesimen dengan sudut $45^{\circ} \%-45^{\circ}$ dengan dengan besar penekanan $60 \mathrm{~N} / \mathrm{mm}^{2}$

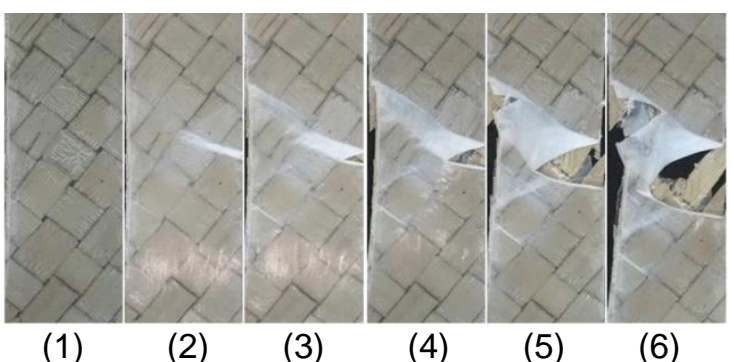

Gambar 16. Fase patahan spesimen dengan sudut $45^{\circ} / 45^{\circ}$ yang memiliki kekuatan paling tinggi dengan lama penekanan $15 \mathrm{~s}$ 
Persentase berat spesimen sudut $0 \% 90^{\circ}$ dan kekuatannya karena daya rekat antar matrik $45 \%-45^{\circ}$ pada variasi penekanan dan waktu dengan serat lebih kecil.

\section{konstan (15 s)}

Gambar 17 menunjukkan perbandingan persentase berat spesimen setelah dilakukan proses penekanan. persentase berat pada spesimen semakin menurun seiring dengan bertambahnya penekanan yang diberikan pada spesimen sedangkan waktu penekanan dibuat sama yaitu $15 \mathrm{~s}$. Hal ini menunjukan bahwa tekanan yang diberikan pada spesimen dapat mempengaruhi berat spesimennya dan juga tebal spesimen. Peristiwa ini disebabkan oleh terlepasnya perekat dari spesimen saat dilakukan penekanan.

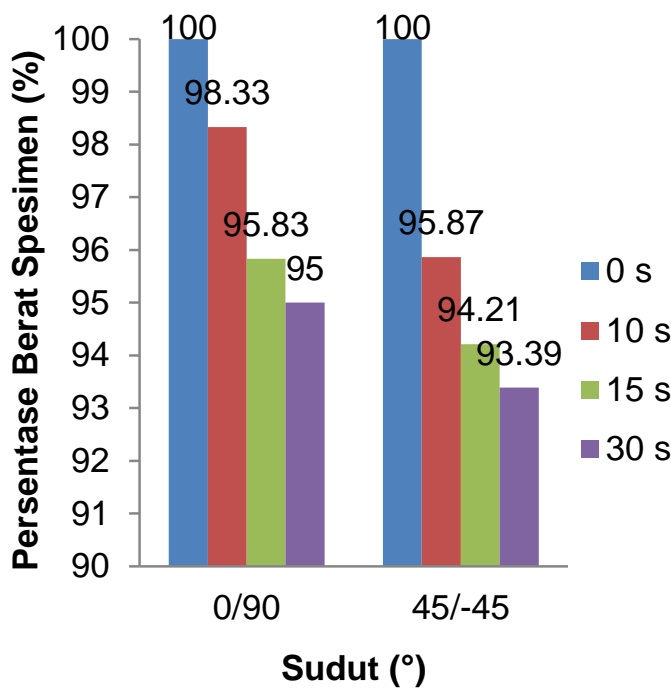

Gambar 17. Perbandingan persentase berat spesimen setelah dilakukan proses penekanan dengan lama penekanan yang sama.

Gambar 18 menunjukan perbandingan persentase berat pada spesimen dengan sudut $0^{\circ} / 90^{\circ}$ dan spesimen sudut $45^{\circ} / 45^{\circ}$ yang semakin menurun seiring dengan lama penekanan yang diberikan pada spesimen dengan penekanan tetap sebesar $60 \mathrm{~N} / \mathrm{mm}^{2}$. Pada gambar terlihat bahwa persentase beratnya semakin menurun, hal ini dikarenakan volume perekat pada spesimen semakin berkurang karna mendapat tekanan yang lama. Sehingga berat spesimen semakin menurun. Semakin banyaknya volume perekat yang keluar, dapat mempengaruhi kekuatan pada spesimen itu sendiri. Semakin sedikit volume perekat pada spesimen maka semakin kecil

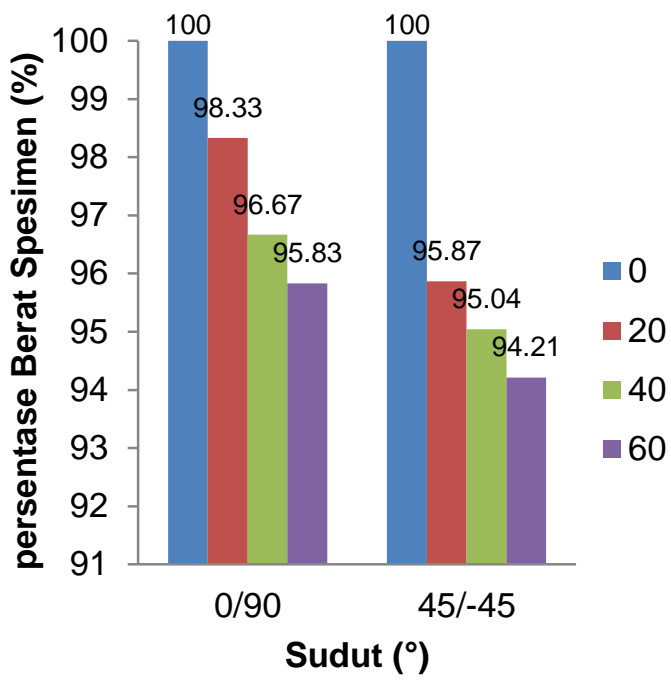

Gambar 18. Perbandingan persentase berat spesimen setelah dilakukan proses penekanan besar penekanan yang sama.

\section{KESIMPULAN}

Dari hasil penelitian pengaruh woven angle dan proses penekanan terhadap orientasi serat dan kekuatan tarik pada natural fiber laminate composite dapat diambil kesimpulan bahwa penambahan tekanan sebesar 60 $\mathrm{N} / \mathrm{mm} 2$ dengan lama penekanan $30 \mathrm{~s}$ memiliki kekuatan tarik tertinggi baik pada woven angle $0^{\circ} / 90^{\circ}$ dan $45^{\circ} /-45^{\circ}$. Akan tetapi, nilai kekuatan tarik pada woven angle $0^{\circ} / 90^{\circ}$ lebih besar daripada $45^{\circ} /-45^{\circ}$. Semakin tinggi tekanan yang diberikan, maka persentase berat perekat pada spesimen semakin berkurang. Fenomena ini akan menyebabkan munculnya delaminasi pada komposit.

\section{DAFTAR PUSTAKA}

[1] K.F. Wang, B.L. Wang. 2018. A Mechanical Degradation Model for Bidirectional Natural fiber Reinforced Composites under Hydrothermal Ageing and Applying in Buckling and Vibration Analysis. Composite Structures 206, pp. 594-600.

[2] Ronald F. Gibson. 1994. Principle of Composite Materials Mechanics. Departement of Metallurgical Engineering, Utah. 
[3] Hilmi Iman Firmansyah, Anindito [9] Budha Maryanti, A. As'ad Sonief dan Purnowidodo, Sofyan Arief Setyabudi. 2018. Pengaruh Mechanical Bonding pada Aluminium dengan Serat Karbon terhadap Kekuatan Tarik Fiber Metal Laminates. Jurnal Rekayasa Mesin Vol.9, No.2, pp. 127-134.

[4] Jufra Daud Johanis Abanat, Anindito Purnowidodo, Yudy Surya Irawan. 2012. Pengaruh Fraksi Volume Serat Pelepah Gebang (Corypha Utan Lamarck) Terhadap Sifat Mekanik Pada Komposit Bermatrik Epoksi. Jurnal Rekayasa Mesin Vol.3, No.2, pp. 352-361.

[5] Rasha M. Sheltami, Ibrahim Abdullah, Ishak Ahmad, Alain Dufresne dan Hanieh Kargarzadeh. 2012. Extraction of Cellulose Nanocrystals from Mengkuang Leaves (Pandanus Tectorius). Corbohydrate Polymers 88, pp. 772-779.

[6] V. Navya Geethika, V. Durga Prasada Rao. 2017. Study of Tensile Strength of Agave Americana Fibre Reinforced Hybrid Composites. Materials Today: Proceedings 4, pp. 7760-7769.

[7] Vignesh P., G. Venkatachalam, A. Gautham Shankar, Anshuman Singh, Rishi Pagaria dan Ankita Prasad. 2018. Studies on Tensile Strength of Sugarcane Fiber Reinforced Hybrid Polymer Matrix Composite. Materials Today: Proceeding 5, pp. 13347-13357.

[8] Goulart, S.A.S., Oliveira, T.A, Teixeira, A., Miléo, P.C., Mulinari, D.R. 2011. Mechanical Behaviour of Polypropylene Reinforced Palm Fibers Composites, Procedia Engineering. 10, pp. 2034-2039.

Slamet Wahyudi. 2011. Pengaruh Alkalisasi Komposit Serat KelapaPoliester terhadap Kekuatan Tarik. Jurnal Rekayasa Mesin Vol.2, No.2, pp. 123-129.

[10] C. Baillie, C. Rose, R. Murphy, T. Nishino, P. Peltola, R. A. Shanks, D. Plackett, S. H. Aziz and M.P. Ansell, M. Sain and S. Panthapulakkal, N. Tucker, A. Hodzic, J. C. Arnold. 2004. Green Composites: Polymer Composites and Environment. Elsevier.

[11] C. Elanchezhian, B. Vijaya Ramnath, G. Ramakrishnan, M. Rajendrakumar, V. Naveenkumar dan M.K. Saravanakumar.2018. Review on Machanical Properties of Natural Fiber Composites. Materials Today: Proceedings 5, pp. 1785-1790.

[12] Nur Ichsan Rusman. 2015. Pengaruh susunan Lamina Komposit Berpenguat Serat E-glass dan Carbon terhadap Kekuatan Tarik dengan Matrik Polyester.

[13] Noni Nopriantina, Astuti. 2013. Pengaruh Ketebalan Serat Pelepah Pisang Kepok (Musa Paradisiaca) terhadap Sifat Mekanik Material Komposit PoliesterSerat Alam. Jurnal Fisika Unand Vol. 2, No. 3.

[14] George E. Dieter. 1992. Metalurgi Mekanik, Jilid 2, Jakarta: Erlangga.

[15] Crawford. R. J. 1998. Plastics Engineering Butterworth Heinemann. 